\title{
Current Status of Mungbean in Madhya Pradesh - A Review
}

\author{
Vinod Kumar* and S.K. Pandey \\ College of Agriculture, Powarkheda, Hoshangabad, Jawaharlal Nehru Krishi Vishwa \\ Vidyalaya - 461110 (MP), India \\ *Corresponding author
}

A B S T R A C T

\section{Keywords \\ Munbean, Production, Disease, Intercropping \\ Article Info \\ Accepted: \\ 10 October 2018 \\ Available Online: \\ 10 November 2018}

Mungbean is one of important crop in India as well as India. Present review is related to mungbean in Madhya Pradesh. Under this study is given the information about farming and field preparation as well as weed management. Also in this review mungbean disease and their control has been studied including water management.

\section{Introduction}

Mungbean is the mature fruit seed of (Vigna radiata $\mathrm{L}$. Wilczek) cultivated in China more than 2000 years, planted in many provinces as crops in tropical and subtropical regions of the Indian subcontinent and in South East Asian countries like Thailand, Philippines, Vietnam, Indonesia, Malaysia, South China and Korea. India is the biggest producer of Mungbean where about 3.83 million ha are cultivated with 1.60 million tonne production (Annual Report-AICRP on MULLaRP 2015-16). Mungbean is excellent source of high quality protein and mineral. The seeds have high $(28 \%)$ protein that is easily digestible, are easy to cook and lack flatulence factors in contrast to other legumes (Sahoo et al., 2003). Mungbean is a rich source of protein (14.6-
$33.0 \mathrm{~g} / 100 \mathrm{~g})$ and iron $(5.9-7.6 \mathrm{mg} / 100 \mathrm{~g})$ (Dahiya et al., 2015). Mungbean contains 1$3 \%$ fat, $50.4 \%$ carbohydrates, $3.5-4.5 \%$ fibers and $4.5-5.5 \%$ ash, while calcium and phosphorus are 132 and $367 \mathrm{mg}$ per 100 grams of seed, respectively (Frauque et al., 2000).

Mungbean is consumed as whole grains, sprouted form as well as dhal in a variety of ways in homes. It is also used as green manuring crop. Mungbean can be used as a feed for cattle even husk of the seed can be soaked in water and used as cattle feed. In India these crops are cultivated in three different seasons, viz., kharif, rabi and summer. Summer Mungbean can be grown after harvesting of chickpea, lentil, pea, potato, mustard, wheat and cotton. Cultivation of Jayad Mungbean is important to increase 
soil fertility in these areas where paddy wheat crop rotation is used.

\section{Crop status of India}

During Twelfth Plan (2012-2017): The total area covered under mungbean in India was 34.50 lakh hectares with a total production of 15.91 lakh tonnes. The coverage of area and its production was maximum in Rajasthan (32.76\% \&30.61\%) followed by Maharashtra $(11.95 \% \& 10.58 \%)$ of the total area and production. Karnataka ranked third in area $(8.81 \%)$ and Tamilnadu is on third position for production $(7.63 \%)$. The highest yield was recorded by the state of Punjab $(845 \mathrm{~kg} / \mathrm{ha})$ followed by Jharkhand (704 kg/ha) and Andhra Pradesh (696 kg/ha). The National yield average was $461 \mathrm{~kg} / \mathrm{ha}$. The lowest yield observed in the state of Karnataka $(227 \mathrm{~kg} / \mathrm{ha})$ followed by C.G. (326 kg/ha) and Odisha (327 $\mathrm{kg} / \mathrm{ha}$ ). During the last three Plan Period area, production and productivity showed increasing trend.

\section{Crop status of Madhya Pradesh}

In Madhya Pradesh during Twelfth Plan (2012-2017) the total area covered under Mungbean 2.51 lakh ha with 1.16 lakh tones total production and productivity was 464 kh/ha (Annual Report DPD 2016-17). Analysing the Madhya Pradesh state, the mungbean crop, district Hoshangabad covered maximum area i.e. 10.2 thousand hectare with followed by Dhar with 7.062 and Chhatarpur, Khargone, Satna and Rewa coverage around 6 thousand hectare. The highest production was in Dhar i.e. 4.70 million tonnes with $7.3 \%$ production tops in the state whereas Hoshangabad with 4.32 million tonnes with $6.7 \%$ on second position and at third position Khargone \& Sidhi around 3 million tonnes. The highest yield was recorded in Bhind 768 $\mathrm{kh} / \mathrm{ha}$ followed by Ratlam $439 \mathrm{~kg} / \mathrm{ha}$, Dhar $420 \mathrm{~kg} / \mathrm{ha}$. The lowest yield was observed in
Mandla $50 \mathrm{~kg} / \mathrm{ha}$ followed by Harda and Dindori. District-wise area, production and yield of top ten district of Madhya Pradesh in respect of production, are presented below which contributed $445 \%$ and $43.7 \%$ percent of area and production of the state (Table 2).

\section{Potential yield (FLD result)}

It is observed that in general average potential yield gap between FLD and farmer's local check yield is about $27 \%$. The potential yield level could be obtained by adoption of improved package of practices. Front Line Demonstration conducted on Mungbean crop with improve variety SML 668 in Madhya Pradesh the improve practice yield was 818 $\mathrm{kg} / \mathrm{ha}$ and farmers yield was $600 \mathrm{~kg} / \mathrm{ha}$ result revealed the increase the yield over check 36.3 $\%$ (Source-ICAR-IIPR, Kanpur). From the table 3 , it is clearly visible that experimental productivity is higher as compare to farmer productivity for each variety. Based on the above criteria for Madhya Pradesh is potential state for production of mungbean. The state occupies 2.5 lakh hectares and has potential where productivity and production could be increased by adoption of recent technologies. In Madhya Pradesh, mungbean production can be increased in five years by reducing $10 \%$ yield gap every year.

\section{Climate requirement}

The crop needs a well-distributed rainfall, high temperature, less humidity. Heavy rains at flowering are harmful, even moist winds at this stage interfere with fertilization. Water logging is fatal for root development and nitrogen fixation during early vegetative stage. Crop is generally grown as rain fed but under assured irrigation during summer in Indo Gangetic plains of Northern India. The additional importance of the seed/soil/water contact zone in influencing sees germination on soil (Fyfield and Gragory, 1989). 


\section{Soil type and field preparation}

Green gram can be grown on a variety of soils ranging from sandy loam to black cotton soils having good drainage capacity. Saline and alkaline soils are not suitable for Mungbean cultivation. Mungbean is very sensitive to water logging conditions. A well prepared seedbed is required for proper germination and establishment of the crop. For this give $2-3$ ploughings followed by planking to make the seedbed free from clods and weeds. For the summer/spring cultivation after the harvesting of last crops, the tillage should be done after irrigation. All land is suitable for Green gram production with varying degrees of suitability where $32.7 \%, 23.7 \%$ and $43.6 \%$ as highly, moderately and marginally suitable respectively. Major limitations that prevent land from being highly suitable include acidity, alkalinity and poor drainage in soils and in some cases steep slopes (Mugo JW et al., 2016).

\section{Sowing time}

Mungbean should be sown during the first week of July to last week of July. For the summer or spring crop, Mungbean should be sown after the harvest of last crop (potato, sugarcane, mustard and cotton, etc). The second fortnight of February to first fortnight of March is most suitable for spring/summer cultivation. Late sown Mungbean takes more loss at the time of flowering stage due to high temperature and yield affected. The early planted crops produced higher yield as compare to late planted crops (Rahman et al., 2004).

\section{Seed rate, spacing and method}

During Kharif season $20 \mathrm{~kg}$ seed/ha should be sown in rows $40-45 \mathrm{~cm}$ apart while during Rabi and Summer $25 \mathrm{~kg}$ seed /ha sown in rows $30 \mathrm{~cm}$ apart. As a companion crop with sugarcane seed rate should be $7-8 \mathrm{~kg} / \mathrm{ha}$. The plant-to-plant distance should be maintained (at least $5 \mathrm{~cm}$ ). Sowing can be done behind the local plough or with the help of seed drill. The row spacing caused remarkable improvement in growth attributes such as plant height, dry matter accumulation, RGR, CGR and NAR at different growth stages which resulted in higher productivity (Mandal et al., 2012).

\section{Seed treatment}

Treat the seed with Thirum (2gm.) +Carbendazim (1gm.) or Carbendazim \& Kepton $(1 \mathrm{gm} .+2 \mathrm{gm})$ to control the soil \& seed germinated disease. For sucking pest control seed treatment with Imidacloprid 70 WS @ $7 \mathrm{~g} / \mathrm{kg}$ or Thiamethoxam $4 \mathrm{~g} / \mathrm{kg}$ seed. It is also desirable to treat the seed with Rhizobium and PSB culture $(5-7 \mathrm{gm} / \mathrm{kg}$ seed). Biofertilizer significantly increase seed germination and decrease incidence of foot and root rot of Mungbean (Mohammad and Hossan 2003).

\section{Cropping systems}

The important crop rotations with moongbean are given as under:

Rice-Wheat-Mung (summer), Maize + Mung Wheat - Mung, Maize (early) - Potato (early)wheat-Mung, Sugarcane+Mung (summer 1:2), Cotton + Mung (1:3 in Central India 60/90 cm paired row).

\section{Intercropping}

During kharif, mungbean are grown generally with maize, pearl millet, pigeonpea and cotton as intercrop. During spring, mungbean is grown in 2:1 ratio with sugarcane with row to row distance of $90 \mathrm{~cm}$. and from mungbean 30 $\mathrm{cm}$ distance maintain. Intercropping with sunflower is also suitable with ratio (2:6). Intercropping of upland rice (Oryza sativa L.) 
with short-duration grain legumes has shown promising productivity and resource use efficiency (Aggarwal et al., 1990).

\section{Manure and fertilizer}

Mungbean is generally grown on the basic fertility of soil. If available 8-10 tonnes of compost or farm yard manure should be applied before 15 days of sowing. For mungbean, per hectare $15-20 \mathrm{~kg}$ nitrogen, 30$40 \mathrm{~kg}$ phosphorus, $20 \mathrm{~kg}$ potash should be applied at sowing time. The fertilizer should be applied by drilling either at the time of sowing or just before sowing in such a way that they are placed about $2-3 \mathrm{~cm}$ below the seed. The application of $\mathrm{N}$ and $\mathrm{P}$ fertilisers significantly increased the see yield (Sadeghipour et al., 2010).

\section{Secondary and micro nutrients}

\section{Sulphur}

In medium black soils and sandy loam soils apply $20 \mathrm{~kg} \mathrm{~S} \mathrm{ha}{ }^{-1}$ (equivalent to $154 \mathrm{~kg}$ gypsum/ phospho-gypsum/ or $22 \mathrm{~kg}$ bentonite sulphur) as basal to each crop. If S deficiency is diagnosed red sandy loam soils, apply $40 \mathrm{~kg}$ $\mathrm{S}$ ha-1 (equivalent to $300 \mathrm{~kg}$ gypsum/phosphogypsum/or $44 \mathrm{~kg}$ bentonite sulphur) per hectare. This quantity is sufficient for one crop cycle. The application of sulphur @ $30 \mathrm{~kg} \mathrm{ha}^{-1}$ significantly increased grain and stover yield of Mungbean (Bahadur and Tiwari (2014) (Table 1).

\section{Zinc}

The Application of $0.5 \% \mathrm{FeSO}_{4}$ and $\mathrm{ZnSO}_{4}$ as foliar spray (before flowering) along with recommended doses of fertilizer in mungbean for enhancement of production, quality and upliftment of their socio-economic status (Singh et al., 2013). Quantity of Zinc requirement determined according to the soil type \& it's availability or status in the soil. Therefore, the doses of zinc should be applied based on the soil type as follows:

Red sandy and loamy soils- $2.5 \mathrm{~kg} \mathrm{Zn} \mathrm{ha}{ }^{-1}$ (12.5 kg zinc sulphate hepta hydrate/ $7.5 \mathrm{~kg}$ zinc sulphate mono hydrate) per hectare.

Black soils- 1.5 to $2.0 \mathrm{~kg} \mathrm{Zn} \mathrm{ha}^{-1}$ (7.5 to $10 \mathrm{~kg}$ zinc sulphate hepta hydrate/ 4.5 to $6.0 \mathrm{~kg}$ zinc sulphate mono hydrate) per hectare.

Laterite, medium and alluvial soils- $2.5 \mathrm{~kg} \mathrm{Zn}$ $\mathrm{ha}^{-1}$ (12.5 kg zinc sulphate hepta hydrate/ 7.5 $\mathrm{kg}$ zinc sulphate mono hydrate) as basal along with $200 \mathrm{~kg}$ of farm yard manure.

High organic carbon containing Tarai soils-3.0 $\mathrm{kg} \mathrm{Zn} \mathrm{ha}{ }^{-1}$ (15 kg zinc sulphate hepta hydrate/ $9 \mathrm{~kg}$ zinc sulphate mono hydrate) as basal once in three year.

Low organic carbon content and hilly sandy loam soil - $2.5 \mathrm{~kg} \mathrm{Zn} \mathrm{ha}{ }^{-1}(12.5 \mathrm{~kg}$ zinc sulphate hepta hydrate/ $7.5 \mathrm{~kg}$ zinc sulphate mono hydrate) as basal in every alternate year.

\section{Boron}

In $\mathrm{B}$ deficient soils, apply $0.5 \mathrm{~kg} \mathrm{~B} \mathrm{~h}^{-1}(5 \mathrm{~kg}$ borax $\mathrm{ha}^{-1} / 3.6 \mathrm{~kg}$ di-sodium tetra borate penta hydrate). The application of phosphorus and boron has synergistic effect on yield, $\mathrm{P}$ and $\mathrm{B}$ content in seed and straw of green gram (Nidhi Kamboj and Malik, 2018).

\section{Manganese}

It is an activator of nitrite reductase and many respiratory enzymes. It is necessary for the evolution of oxygen (photolysis) during photosynthesis. Functions with enzyme systems involved in breakdown of carbohydrates, and nitrogen metabolism. In manganese deficient sandy loam soils, Seed soaking with $2 \%$ manganese sulphate OR 
foliar spray of $1 \%$ manganese sulphate is recommended.

\section{Molybdenum}

In molybdenum deficient soils, application of $0.5 \mathrm{~kg}$ Sodium Molybdate /ha as basal or two foliar sprays of $0.1 \%$ Sodium Molybdate or seed treatment is recommended.

\section{Water management}

Generally the kharif crop requires one life saving irrigation, which may be applied during the early pod formation stage. For the summer/spring mungbean, 3-4 irrigations are required. Apply first irrigation after 20-25 days of sowing and repeat after 10-15 days as per need. One irrigation before flowering and another at pod-filing stage would ensure healthy seeds. Water logging in the field should be avoided at all cost. No irrigation should be given when the crop is in full bloom stage.

\section{Integrated weed management}

Yield losses in Mungbean due to weeds have been estimated to range between $30-50 \%$ (Kumar et al., 2004). For effective weed control use Pre- emergence herbicide @ 0.75 $\mathrm{kg}$ pendimetheline $30 \mathrm{EC}+$ Imazethapyr $2 \mathrm{EC}$ with 600 liter water or 1lt ai fluclorelin with 800 liter water.

For post emergence the imazethapyr @ 0.075 $\mathrm{kg} / \mathrm{ha}$ applied 20-25 days after sowing was the most remunerative and effective herbicide for controlling the complex weed flora in Mungbean (Khairnar et al., 2014).

Or the quizalofop-p-ethyl $50 \mathrm{~g}$ a.i. ha-1 at 21 day after emergence (DAE) + hand weeding (HW) at 28 DAE (Kundu et al., 2009). Always flat nozzle is used during spraying of weedicide.

\section{Integrated pest management}

Insect pests can attack mungbeans at any stage from seedling to harvest but the crop is most susceptible from budding onwards. It is important to monitor crops once a week during vegetative growth as the first buds are borne below the top of the canopy.

\section{Diseases}

\section{Yellow mosaic virus}

\section{Symptoms}

This disease is caused by the mungbean yellow mosaic virus (MYMV) belonging to Gemini group of viruses. The disease starts as small yellow specks along the veinlets and in severe form covers the entire lamina. Whitefly (Bemisia tabaci) transmits this geminivirus in the persistent (circulative) manner. The host range is confined mostly to members of the Leguminosae family. The economic losses due to this virus account up to $85 \%$ in green gram which is spreading faster towards newer areas (Karthikeyan et al., 2014).

\section{Control measure}

Diseased plants should be rouged out to prevent further spread of the disease. Seed treatment with imidacloprid at $5 \mathrm{ml} / \mathrm{kg}$ seeds and two sprays of imidacloprid at $0.5 \mathrm{ml} / \mathrm{l}$ at 25 and 40 days after sowing (DAS) or two sprays of imidacloprid at $0.5 \mathrm{ml} / 1$ alone at 25 and 40 DAS were found effective in reducing the incidence of MYMV and its vector. Seed treatment with imidacloprid at $5 \mathrm{ml} / \mathrm{kg}$ seeds plus two sprays of neemazal at $3 \mathrm{ml} / \mathrm{l}$ was also effective in management of MYMV and its vector (Jayappa et al., 2017). Grow tolerant/resistant varieties like Meha, TJM-3, PDM 139 (Samrat), PDM 11, PKV AKM-4, HUM 2, IPM 02-14, MH 421, IPM 410-3 (Shikha) and IPM 205-7 (Virat). 


\section{Crop status of Madhya Pradesh}

\begin{tabular}{|l|}
\hline District \\
\hline HOSHANGABAD \\
\hline DHAR \\
\hline CHATTARPUR \\
\hline KHARGONE \\
\hline SATNA \\
\hline REWA \\
\hline SHIVPURI \\
\hline SIDHI \\
\hline TIKAMGARH \\
\hline BARWANI \\
\hline
\end{tabular}

\begin{tabular}{|r|l|r|}
\hline Area 000 ha & District & Production MT \\
\hline 10.2 & DHAR & 4.70 \\
\hline 7.062 & HOSHANGABAD & 4.32 \\
\hline 6.68 & KHARGONE & 3.37 \\
\hline 6.2776 & SIDHI & 3.26 \\
\hline 6.184 & SHIVPURI & 2.38 \\
\hline 6.02 & CHATTARPUR & 2.29 \\
\hline 5.59 & BARWANI & 2.22 \\
\hline 5.56 & REWA & 2.01 \\
\hline 5.36 & NARSINGHPUR & 1.97 \\
\hline 5.3 & JABALPUR & 1.93 \\
\hline
\end{tabular}

Table.1 Nutritive value

\begin{tabular}{|l|}
\hline Protein \\
\hline Fat \\
\hline Minerals \\
\hline Fiber \\
\hline Carbohydrate \\
\hline
\end{tabular}

$24-2$
$1.3 \%$
$3.5 \%$
$4.1 \%$
$56 \%$

Calcium

Phosphorus

Iron

$56 \%$
Calorific value

Moisture
$124 \mathrm{mg} / 100 \mathrm{~g}$

$326 \mathrm{mg} / 100 \mathrm{~g}$

$7.3 \mathrm{mg} / 100 \mathrm{~g}$

$334 \mathrm{Kcal} / 100 \mathrm{~g}$

$10 \%$

Table.2 Recommended varieties for Madhya Pradesh

\begin{tabular}{|c|c|c|c|c|c|c|}
\hline $\begin{array}{l}\text { S. } \\
\text { No. }\end{array}$ & $\begin{array}{l}\text { Name of } \\
\text { variety }\end{array}$ & $\begin{array}{l}\text { Year of } \\
\text { Release }\end{array}$ & $\begin{array}{l}\text { Average } \\
\text { yield } \mathrm{q} / \mathrm{ha}\end{array}$ & $\begin{array}{l}\text { Days to } \\
\text { Maturity }\end{array}$ & $\begin{array}{l}\text { Reaction to major } \\
\text { diseases }\end{array}$ & Remark \\
\hline 1. & BM-4 & 1992 & $10-12$ & $65-70$ & Tol. To MYMV \& PM & $\begin{array}{l}\text { Recommended for } \\
\text { Kharif }\end{array}$ \\
\hline 2. & JM-721 & 1995 & 12.4 & $70-75$ & Tol. To PM & $\begin{array}{l}\text { Recommended for } \\
\text { Kharif }\end{array}$ \\
\hline 3. & HUM 1 & 1999 & 9.0 & 65 & Resistant to MYMV & $\begin{array}{l}\text { Recommended for } \\
\text { Kkarif \& summer }\end{array}$ \\
\hline 4. & $\begin{array}{l}\text { PUSA } \\
9531\end{array}$ & 2000 & 9.0 & 60 & Resistant to MYMV & $\begin{array}{l}\text { Recommended for } \\
\text { summer }\end{array}$ \\
\hline 5. & AKM 8802 & 2000 & $10-11$ & $61-63$ & $\begin{array}{c}\text { Moderately resistant to } \\
\text { MYMV }\end{array}$ & $\begin{array}{l}\text { Recommended for } \\
\text { Kharif }\end{array}$ \\
\hline 6. & PDM 139 & 2001 & $10-12$ & $58-62$ & $\begin{array}{l}\text { Highly resistant to } \\
\text { MYMV, Erect, } \\
\text { synchronous }\end{array}$ & $\begin{array}{l}\text { Recommended for } \\
\text { summer cultivation in } \\
\text { MP }\end{array}$ \\
\hline 7. & Meha & 2004 & $12-15$ & $65-70$ & $\begin{array}{c}\text { Early maturity, MYMV } \\
\text { resistance }\end{array}$ & $\begin{array}{l}\text { Recommended for } \\
\text { summer cultivation }\end{array}$ \\
\hline 8. & TJM-3 & 2007 & 9.5 & 65 & $\begin{array}{c}\text { Resistant to MYMV, CLS } \\
\text { \& PM }\end{array}$ & $\begin{array}{l}\text { Recommended for } \\
\text { Kharif }\end{array}$ \\
\hline 9. & $\begin{array}{c}\text { PKV } \\
\text { AKM-4 }\end{array}$ & 2009 & 10.0 & $62-66$ & Resistant to MYMV & $\begin{array}{l}\text { Recommended for } \\
\text { Kharif }\end{array}$ \\
\hline 10. & $\begin{array}{l}\text { IPM 410-3 } \\
\text { (Shikha) }\end{array}$ & 2016 & $11-12$ & $65-70$ & $\begin{array}{l}\text { Highly resistant to MYMV } \\
\text { and powdery mildew }\end{array}$ & $\begin{array}{l}\text { For Summer/ } \\
\text { spring season }\end{array}$ \\
\hline 11. & $\begin{array}{l}\text { IPM 205-7 } \\
\text { (Virat) }\end{array}$ & 2016 & $10-11$ & $52-56$ & Resistant to MYMV & $\begin{array}{l}\text { For Summer/ } \\
\text { Season }\end{array}$ \\
\hline
\end{tabular}

Source: - PC, AICRP on MULLaRP, Report 2016-17 
Table.3 Experimental yield of dominating varieties $(\mathrm{kg} / \mathrm{ha})$

\begin{tabular}{|c|l|c|c|c|c|c|r|}
\hline S. No. & Varieties & $2011-12$ & $2012-13$ & $2013-14$ & $2014-15$ & $2015-16$ & Mean \\
\hline 1. & AKM 8802 & 1696 & 1107 & 634 & 972 & 403 & 962.4 \\
\hline 2. & PKV AKM 4 & 2074 & 1448 & 315 & 1326 & 519 & 1136.4 \\
\hline 3. & BM 4 & - & 1191 & 833 & 878 & 726 & 725.6 \\
\hline
\end{tabular}

Source- Annual Report AICRP on MULLaRP

\section{Leaf curl}

\section{Symptoms}

The symptoms are visible first in third leaf after three to four weeks of sowing. The symptoms are downward curing of leaves veinal necrosis, chlorotic spots and chlorosis on the lamina, stunting and death of the plants due to apical necrosis on green gram. Symptoms are conformity with Nene (1972). The affected plants, however, do not die till the harvest of the crop.

\section{Control measures}

Treat the seeds with imidacloprid 70 WS@ $5 \mathrm{ml} / \mathrm{kg}$; Foliar spray of insecticide (dimethoate 30 EC @ 1.7ml/ha) on 30 days after sowing; Select resistant varieties whenever possible i.e. SAMRAT (PDM 139), PS 16; Leaf curl can be controlled by applying sulfur or copper-based fungicides that are labeled for use on peaches and nectarines. For best results, trees should be sprayed to the point of runoff or until they start dripping; Containing copper and pyrethrins, Bonide ${ }^{\circledR}$ Garden Dust is a safe, one-step control for many insect attacks and fungal problems; Keep the ground beneath the trees raked up and clean, especially during winter months; Prune and destroy infected plant parts as they appear If disease problems are severe, maintain tree health and vigor by cutting back more fruit than normal, watering regularly (avoiding wetting the leaves if possible) and apply an organic fertilizers high in nitrogen.

\section{Anthracnose}

\section{Symptoms}

Anthracnose caused by Colletotrichum gloeosporioides is the causal organism affecting aerial plant parts, however, the leaves and pods are more vulnerable.

The characteristic symptoms of this disease are circular brown sunken spots with dark centers and bright red orange margins on leaves and pods. Infection just after germination causes seedling blight. The average seed yield loss of 40.18 per cent and stalk yield loss of 46.90 per cent was noticed due to anthracnose of mungbean (Kulkarni, 2009).

\section{Control measures}

Hot water seed treatment at $58^{\circ} \mathrm{C}$ for 15 minutes has been found effective in checking the seed-borne infection and increasing proportion of seed germination. The seed treatment with Thiram $75 \mathrm{SD}, 3 \mathrm{~g} / \mathrm{kg}$ seeds + two foliar sprays at 15 days interval starting from initiation of disease with trifloxystrobin + tebuconazole (75 WG), 0.075 per cent or with carbendazim + mancozeb (75WP), 0.075 percent (Chaudhari and Gohel 2016).

\section{Cercospora leaf spot}

\section{Symptoms}

It is most important fungal disease of mungbean. Leaf spots are circular and 
irregular in shape with brown to greyishwhite centres and reddish-brown to dark brown margins. Such spots are also visible or pods are the affected pods become blackened.

\section{Control measures}

i) Field sanitation, crop rotation, destruction of infected crop debris; ii) Opt for resistant varieties as per recommendation of local agricultural authorities (Like- LM 113, LM 168, LM 170, JM 171, Ganga 1, HUM 12, Pusa 06722); iii) Treat the seeds with thiram or captan @ $2.5 \mathrm{~g} / \mathrm{kg}$ of seed; iv) On appearance of the symptoms spray with carbendazim 50 WP @1.0 g/liter or mancoze 75 WP @2.0 g/liter or hexaconazole (contaf $5 \%$ EC)@1 ml/ liter of water. Subsequent spray should be done after 10 to 15 days, if required. Spraying with copper oxychloride @ 3 to $4 \mathrm{~g} /$ liter water has also been found effective in management of the disease.

\section{Insect-pest management}

Numerous insect pests attack the mungbean. The loss in the production caused by them may reach up to $70 \%$ depending upon the severity of attack. Some common insect pests of mungbean and their management are as follow:

\section{White fly}

\section{Nature of damage}

The infested plants become very weak showing downward cupping of he leaves giving a sickly look and the plant may die Insect secretes honey dew on leaves results blackening of leaves, drastically reducing photosynthetic rate and drying of leaves.

Whitefly is a vector of number of viral diseases especially mungbean yellow mosaic virus (MYMV).

\section{Control measures}

i) Seed treated with Dimethoate 30 EC @ $5 \mathrm{ml} / \mathrm{kg}$; ii) Foliar spray of Triazophos 40 EC @ $2.0 \mathrm{ml} / 1$ or Malathion $50 \mathrm{EC}$ @ $2.0 \mathrm{ml} / 1$ at 10-15 days intervals if required; iii) Grow cotton as a trap crop one month earlier between the mungbean rows; iv) Grow maize, sorghum or pearl millet as a barrier crop to minimize the incidence of whiteflies; v) Install Sticky trap; vi) Opt. resistant varieties e.g. ML 1256, ML 1260 and ML 1191

\section{Bean thrips}

\section{Nature of damage}

The thrips nymphs and adults feed on stigma inside the flower, flower sheds before opening and there is elongation of terminal shoot. Plants attain a bushy growth and the crop looks dark-green in colour, bearing few pods with shrivelled grains.

\section{Control measures}

i) Seed treatment with Thiomethoxam $70 \mathrm{WS}$ @ $2 \mathrm{ml} / \mathrm{kg}$ seed + foliar spray of Thiomethoxam $25 \mathrm{WG} 0.2 \mathrm{~g} /$ liter of water of is quite effective in controlling bean thrips; ii) Spray neem seed kernel extract $(50 \mathrm{~g} / \mathrm{l})$ and neem oil 3000 ppm @ $20 \mathrm{ml} / \mathrm{l}$; iii) Opt for resistant varieties (Mungbean: PIMS 2, PMS 3, 12-333, Co 3, ML 5, ML 337; iv) Timely irrigation at an interval of 15 days results in low build-up of thrips; v) The incidence of bean thrips can be minimized by intercropping mungbean with cotton; vi) Spray of Triazophos 40 EC @ $2.0 \mathrm{ml} / \mathrm{liter}$, Ethion50 EC@2 ml/liter of water.

\section{Stem fly}

\section{Nature of damage}

Stem fly (Ophiomyia phaseoli) maggots mine the leaves or bore into the leaf petiole or 
tender stem resulting in withering, drooping and death of plant. The characteristic symptoms of damage include drooping of the first two leaves and yellowing of plants. It can cause $5-20 \%$ damage in mungbean.

\section{Control measures}

i) Follow clean cultivation, crop rotation, earthing up, growing trap crop, destroying alternative hosts like Solanum nigrum to minimize the stem fly incidence; ii) Opt for resistant varieties (Mungbean: CoGG 912 \& CoGG 917; Urdbean: CoBG 671 \& AC 222); iii) Seed soaking either in imidacloprid 17.8 SL@ $9.0 \mathrm{ml} / \mathrm{kg}$ seed in $100 \mathrm{ml}$ water for one hour or thiomethoxam 25 WG @ 5.0 g/kg seed in $100 \mathrm{ml}$ water to avoid early incidence of stem fly is recommended; iv) Spray either Imidacloprid $17.8 \quad \mathrm{SL}$ @ $0.2 \mathrm{ml} / 1$ or thiomethoxam $25 \mathrm{WG} @ 0.3 \mathrm{~g} / \mathrm{lit}$ at 15 days after sowing.

\section{Bihar hairy caterpillar}

\section{Nature of damage}

Female moths lay eggs on plants in a field. Young caterpillar eats away all the green matter of the leaves and it can be easily recognized by perforated, dusty white coloured leaves in the field. The grown-up caterpillars feed voraciously on leaves, soft stems and branches. The insect totally denude the crop within few days resulting in total failure of the crop.

\section{Control measures}

i) Uproot the damaged plants along with the young larvae at the gregarious phase and burry under the soil; ii) Spray of Quinalphos 25 EC @ 2.5 ml/liter or Dichlorvos 10 EC@ $1.0 \mathrm{ml} /$ liter or Fenvalerate $20 \mathrm{EC} @ 1.87 \mathrm{ml} /$ liter of water or dusting with Fenvalerate $0.4 \% @ 15$ kg/ha.

\section{Harvesting threshing and storage}

Mung should be harvested when more than 80 per cent pods mature. One or two rounds of picking of pods are also recommended to avoid losses due to shattering. The plants are cut with the sickle and dried on the threshing floor. These are then threshed by beating with sticks or by trampling with bullocks.

The clean seeds should be sun dried for 3-4 days to bring their moisture content at $8-10 \%$ to safely store in appropriate bins.

\section{Yield}

A well-managed crop, as indicated above, may produce 8-10 quintals and in mixed crop yield 3-5 quintals grains per ha. In rainy season crop produce 10 qtls/ha and in summer crop produce 12-15 qtls. /ha. In mixed cropping 3-5 qtls/ha.

\section{Recommendation to achieved higher production}

Deep summer ploughing once in 3 years.

Seed treatment should be done before sowing.

Application of fertilizer should be based on soil test value.

In kharif season sowing should be done by ridge $\&$ furrow method.

Yellow mosaic resistant/ tolerant varieties Narendra Mung1, Pant Mung 3, PDM 139 (Samrat), PDM 11, MUM 2, ML 337, IPM 02-14, MH 421, SML 832 etc. choose as per suitability of region.

Weed control should be done at right time.

Adopt integrated approach for plant protection. 
Global supplies of pulses are limited, as India happens to be the largest producer and consumer of pulses. India needs around 32 million tons of pulses by 2030 , to feed the estimated population of about 1.68 billion. Hence, India needs to produce the required quantity, but also remain competitive to protect indigenous pulses including mungbean production. Improved technologies like improved, high yielding varieties and appropriate crop management practices are available. However, great efforts by farmers, researchers, and government agencies are there to ensure that India becomes selfsufficient in pulses in the next coming years. The programs initiated by the government are bearing fruits, and it is hoped that this momentum is sustained and strengthened to make India self-sufficient in pulses. During the last three Plan Period area fluctuating, however, production and productivity showed increasing trend. The yield of most of the potential districts were below the National average yield need to be adopt Improved Package of Practices of the Mungbean to increase the production in districts as well as state and country.

\section{References}

Aggarwal, $\quad$ P. $\quad$ K., D. $\quad$ P. Garrity, S. P. Liboon and R. A. Morris (1990). Resource Use and Plant Interactions in a Rice-Mungbean Intercrop. Agronomy Journal. 84 (1), p. 71-78

Annual Report DPD 2016-17DPD/Pub/TR/19/2016-17

Chaudhari, Kinjal A. and N. M. Gohel (2016). Management of anthracnose disease of mungbean through new fungicidal formulations. Journal of Pure and Applied Microbiology, 10(1), P. 691-696.

Dahiya, P. K., A. R. Linnemann, M. A. J. S. Van Boekel, N. Khetarpaul, R. B. Grewal and M. J. R. Nout Mung Bean:
Technological and Nutritional Potential. Crit Rev Food Sci Nutr. 2015; 55 (5):670-88.

Frauque, A., T. Haraguchi, O. Hirota, and M. A. Rahman (2000). Growth analysis, yield, and canopy structure in maize, mungbean intercropping. Bu. Inst. of Tropical Agric. Kyushu University Fukuoka, Japan, 23: 61-69.

Fyfield, T. P. and P. J. Gragory (1989) Effects of Temperature and Water Potential on Germination, Radicle Elongation and Emergence of Mungbean. Journal of Experimental Botany. 40 (6), Pp 667674.

Jayappa, HK Ramappa and BD Devamani (2017). Management of Mungbean Yellow Mosaic Virus (MYMV) in Mungbean (Vigna radiata L.). Journal of Entomology and Zoology Studies, 5(5): 596-601.

Kamboj, Nidhi and R.S. Malik (2018) Influence of Phosphorus and Boron Application on Yield, Quality, Nutrient Content and Their Uptake by Green Gram (Vigna radiate L.). Int. J. Curr. Microbiol. App. Sci 7(3): 1451-1458.

Karthikeyan, A., V.G. Shobhana, M. Sudha, M. Raveendran, N. Senthil, M. Pandiyan and P. Nagarajan (2014) Mungbean yellow mosaic virus (MYMV): a threat to green gram (Vigna radiata) production in Asia. International Journal of Pest Management, 60:4, 314-324.

Khairnar, C.B., V.V. Goud and H.N. Sethi (2014). Pre- and post-emergence herbicides for weed management in mungbean. Indian Journal of Weed Science 46(4): 392-395.

Kulkarni, S. A. (2009). Epidemiology and integrated management of anthracnose of green gram. M.Sc. (Agri.) Thesis submitted to UAS, Dharwad, Karnataka. 
Kumar R, Thakral SK and Kumar S. 2004. Response of mungbean (Vigna radiate L.) to weed control and fertilizer application under different planting system. Indian Journal of Weed Science 36: 131-132.

Kundu, R., P. S. Bera and K. Brahmachari (2009). Effect of different weed management practices in summer mungbean [Vigna radiata L.] under new alluvial zone of West Bengal. Journal of Crop and Weed, 5(2): 117-121.

Lal Bahadur and D.D. Tiwari (2014). Nutrient Management in Mung Bean (Vigna radiata L.) Through Sulphur and Biofertilizers. Legume Res., 37 (2): 180 $-187$.

Mandal J., R, Mallick and H. Banerjee (2012). Growth and yield of green gram (Vigna radiata) as affected by rowspacing and foliar application of nutrients. Research on Crops.13(2):525528 .

Mohammad, D. and I. Hossain (2003). Seed Treatment with Biofertilizer in Controlling Foot and Root Rot of Mungbean. Plant Pathology Journal, 2: 91-96.

Mugo, J. W., P.C Kariuki and M. D. K Musembi (2016). Identification of Suitable Land for Green Gram Production Using GIS Based Analytical Hierarchy Process in Kitui County,
Kenya. Journal of Remote Sensing \& GIS. ISSN: 2469-4134.

Nene YL. Disease of mung and urd bean. 4. Leaf curl in Nene YL (ed.). A survey of viral diseases of pulse crops in Uttar Pradesh, University Press, Pantnagar, India. 1972, 142-153.

Rahman Md. A. S., Md. H. Kabir, M. Begum and Md. A. Salam (2004). Yield Performance of Mungbean as Affected by Planting Date, Variety and Plant Density. Journal of Agronomy.3 (1): 1824 ,

Sadeghipour, O., R. Monem and A.A. Tajali (2010). Production of Mungbean (Vigna radiata L.) as Affected by Nitrogen and Phosphorus Fertilizer Application. Journal of Applied Sciences, 10: 843847.

Sahoo, L., Sugla, T. and Jaiwal, P.K. In vitro regeneration and genetic transformations of Vigna species. In Jaiwal, P.K., Singh, R.P. (eds.) Biotechnology for the improvement of legumes. Kluwer Acad Publ, Netherlands, 2003; pp. 1-48.

Singh, Vijayata, R. K. Yadav, Rajesh Yadav, R. S Malik, N. R. Yadav, Jogendra Singh and M. D. Meena (2013). Effect of different iron and zinc application on growth, yield and quality parameters of mungbean (Vigna radiata L.). Annals of Agri Bio Research. 18 (2), pp.164-175.

\section{How to cite this article:}

Vinod Kumar and Pandey, S.K. 2018. Current Status of Mungbean in Madhya Pradesh - A Review. Int.J.Curr.Microbiol.App.Sci. 7(11): 1062-1072. doi: https://doi.org/10.20546/ijcmas.2018.711.123 